\title{
Analysis of the Relevance of Information Content of the Value Added Statement in the Brazilian Capital Markets
}

\author{
Márcio André Veras Machado \\ Ph.D Professor, Department of Management, Federal University of Paraíba \\ E-mail: mavmachado@hotmail.com \\ Marcelo Alvaro da Silva Macedo \\ Ph.D Pröfessor, Department of Accounting Sciences, Federal University of Rio de Janeiro \\ Ė-mail: malvaro.facc.ufrj@gmail.com \\ Márcia Reis Machado \\ Ph.D Professor, Department of Finances and Accounting, Federal University of Paraíba \\ E-mail:marciareism@hotmail.com

\begin{abstract}
The usefulness of financial statements depends, fundamentally, on the degree of relevance of the information they disclose to users. Thus, studies that measure the relevance of accounting information to the users of financial statements are of some importance. One line of research within this subject is in ascertaining the relevance and importance of accounting information for the capital markets: if a particular item of accounting information is minimally reflected in the price of a share, it is because this information has relevance, at least at a certain level of significance, for investors and analysts of the capital markets. This present study aims to analyze the relevance, in the Brazilian capital markets, of the information content of the Value Added Statement (or VAS) - referred to in Brazil as the Demonstração. do Valor Adicionado, or DVA. It analyzed the ratio between stock price and Wealth created per share (WCPS), using linear regressions, for the period 2005-2011, for non-financial listed companies included in Melhores \& Maiores ('Biggest \& Best'), an annual listing published by Exame Magazine in Brazil. As a secondary objective, this article seeks to establish whether WCPS represents a better indication of a company's result than Net profit per share (in this study, referred to as NPPS). The empirical evidence that was found supports the concept that the VAS has relevant information content, because it shows a capacity to explain a variation in the share price of the companies studied. Additionally, the relationship between WCPS and the stock price was shown to be significant, even after the inclusion of the control variables Stockholders' equity per share. (which we abbreviate in this study to SEPS) and NPPS. Finally, the evidence found indicates that the market reacts more to WCPS (Wealth created per share) than to NPPS. Thus, the results obtained give some indication that, for the Brazilian capital markets, WCPS may be a better proxy concept for referring to a company's result than NPPS.
\end{abstract}

Keywords: relevance of accounting information, Value Added Statement, wealth created. 


\section{INTRODUCTION}

The usefulness of financial statements depends, fundamentally, on the relevance of the information that is published to users. In general, accounting information can be said to be relevant when it has certain characteristics, such as: (i) that it helps to reduce the asymmetry of information between internal users (e.g. managers, executives, etc.) and external users of the company (stockholders, creditors, government, etc.); or (ii) that it helps the user to evaluate the potential effect of past, present and future transactions on future cash flows (predictive value) and/or to confirm or correct prior evaluations (confirmatory value); or (iii) when its use alters the user's decision, that is to say, when the user takes a different decision than he/she would otherwise have taken without certain information.

The relative importance of accounting information can be observed from various points of view, since there is a variety of users. Studies that seek to analyze the relationship between companies' market value and accounting figures are referred to as "value relevance" studies. These studies aim to determine the relevance of a given item of information to the capital markets, by seeing whether that information is reflected in a company's stock prices. Barth, Beaver, and Landsman (2001) considered an item of information to be relevant if it was correlated with the company's market valuation.

These studies, as Brown, Lo, and Lys (1999) point out, are normally made using regression analyses, using as a dependent variable a proxy related to the share price, and as independent variables certain accounting information, most commonly proxies related to profit and stockholders' equity. Barth et al. (2001) add that these surveys are focused on the coefficients of the items of accounting information in the regression equation. In other words, to be of importance, an item of accounting information has to have a non-zero coefficient in the regression equation.

Some of the studies of this type, referred to as Relative Association Studies, aim to make a comparative analysis of the importance of alternative accounting information items. Recently, some of these studies have looked at the effects of the process of harmonization of Brazilian accounting rules with international financial reporting standards.

In Brazil, this process of convergence began officially with Law 11638 of 2007, which changed Law 6404/1976 (known in Brazil as 'the Corporate Law'), making several changes to accounting law so as to approximate Brazilian accounting to international accounting.

Law 11638/07 introduced a mandatory requirement for listed companies to publish a Value Added Statement (VAS), which until that time had not been required in Brazil - although some companies were publishing one voluntarily. Note also that this statement is not required under International Financial Reporting Standards (IFRS), issued by the International Accounting Standards Board (IASB). However, the Global Reporting Initiative (GRI) uses Economic Value Generated and Distributed (EVG\&D) as a performance indicator. This is very similar to the indication of value added presented in the VAS, the main difference being inclusion in economic value distributed of investments in the community - which include voluntary contributions and investment of funds in the community as a whole. This fact shows a perceived relevance of value added created and distributed, and also its recognition internationally, whether in the manner suggested in the guidelines of the GRI, or according to current accounting standards.

Accounting is not only a technique. It is recognized that social questions can influence accounting and that this, in turn, can mobilize and change the behavior of the user. However, these interactions have been little investigated. The relationship between accounting and social aspects is usually indicated and presumed, we can say, rather than described and analyzed (Burchell, Clubb, \& Hopwood, 1985).

From the point of view of accounting as an institutional and social practice, in the view of authors of the British school, in the 'perfect world (the hypothesis of efficient markets, without transaction costs, information perfectly disseminated between agents, etc.) that economists tend to use as a basis of work, there is no space for accounting' (Lopes \& Martins, 2005, p. 24). On this line of thinking, accounting needs to be widely inserted into a social and cultural context (Burchell et al., 1985; Lopes \& Martins, 2005; Zanchet \& Martins, 2011).

The Value Added Statement (VAS), the focus of this investigation, exists in this context - since it is a statement that aims to show the value added generated by the entity, and how this value is distributed between all those who have made the effort to create that value, which includes not only the holders of capital, but also employees, who provide the workforce, other parties that finance the company's activity, society as a whole - through charges and contributions paid to the government, and how much is retained in the company.

It is in this context, then, that an attempt is thus made to analyze the effect of publication of a VAS being made obligatory - by means of a value relevance study of the information about wealth created; and whether the VAS contains information that is relevant for the Brazilian capital markets.

In other words the study aims to ascertain the relevance of the information content of the VAS for the Brazilian capital markets. It analyses the relationship between share price and the VAS of non-financial listed companies included in the list of Maiores \& Melhores, adopting Wealth Created Per Share (WCPS) as a proxy for the result of the VAS, for the period 2005 through 2011. Maiores \& Melhores ('Biggest and Best') is a listing published annually by Exame Magazine, in partnership with the Accounting, Actuarial and Financial Studies Foundation (Fundação Instituto de Pesquisas Contábeis, Atuárias e Financeiras, or FIPECAFI). As a second objective, this article seeks to find out whether WCPS, in that period, was a better proxy than Net Profit 
Per Share (NPPS), which is a measurement commonly used as a proxy for accounting information.

A sufficient reason for this survey would be the fact that studies on the subject are scarce, possibly because the value added statement is not obligatory, internationally, and in Brazil has been obligatory only for listed companies, and only since 2007. It is known that inclusion of a new obligatory statement causes an increase of work, and consequently costs, for its preparation, auditing and publication - a further justification for studies investigating whether providing it does provide benefit to users. And this can be studied by consideration from the point of view of value relevance. Finally, earlier studies exist, but their results have not yet provided sufficient grounds for a significant statement on whether the VAS has information content, especially since they covered shorter periods.

This article has five sections. The next (Section 2) presents the theoretical framework, dealing with the concept of the relevance of accounting information, and the Value Added Statement. Section 3 deals with methodology; and Section 4 with the results of the investigation. The fifth section is the conclusion, and is followed by the bibliography.

\section{VALUE RELEVANCE: THE STUDY OF THE RELEVANCE OF ACCOUNTING INFORMATION}

The aim of accounting is to measure and communicate the group of economic events related to the results of the subject entity. Relevant accounting information can be considered to be whatever changes the 'state of the art' of the entity's user's knowledge about the entity, since, after interpretation, he/she uses it to solve problems (Yamamoto \& Salotti, 2006).

In this sense, the study of the role of accounting as provider of information to the capital markets is extremely important for evaluating the efficiency of accounting information (Iudícibus \& Lopes, 2004). The importance of information for the capital markets is not only in the question of allocation of funds, but also in the establishment of prices of securities, after risks and returns have been considered (Hendriksen \& van Breda, 1999).

Thus, using the financial market as their test laboratory, these studies seek to establish the relevance of a given item of accounting information for the capital markets. In other words, they seek to establish whether accounting information is able to help users evaluate the potential effects of past, present and future transactions (i.e. whether it has predictive value), and/or confirm or correct their prior valuations (confirmatory value), based on the efficient markets hypothesis - that prices of shares reflect all and any information that is relevant and available, and adjust themselves as a function of this group of information (Famá, 1970).

Holthausen and Watts (2001) classify value relevance studies in three categories, and any individual study may be in more than one of them: (i) "Relative association studies", which, like this present study, compare the association between the market value of shares (or changes in those values) and various forms of measurement, such as an existing accounting standard, or one that is being proposed. These studies normally compare the $\mathrm{R}^{2}$ of regression models, in which an accounting standard with a higher $\mathrm{R}^{2}$ is evaluated as more relevant; (ii) "Incremental association studies", which investigate whether the accounting component analyzed serves as an indicator of figures such as, for example, profit or returns, over periods of time (it being important to include other variables). A factor is considered to be relevant if its estimated regression coefficient is significantly different from zero; and (iii) "Marginal information content studies", which investigate whether a given factor increases investors' power in relation to the information available. Typically, event study methodologies are used, in which the interest lies in assessing whether the availability of certain information is associated with alterations of asset value (price reactions) - in which reactions are considered to be indications of relevance.

There are various studies that aim to ascertain the relevance of accounting information. These start with Ball and Brown (1968), and Beaver (1968), which, according to Yamamoto and Salotti (2006) were the precursors of this type of study. Other important studies, according to Kothari (2001), and Iudícibus and Lopes (2004), have been: Beaver, Clarke, and Wright (1979); Beaver, Lamber, and Morse (1980); Collins, Maydew, and Weiss (1997); Brown et al. (1999); and Lopes (2001, 2002a and 2002b).

Other studies to be mentioned include: Foster (1977); Board and Walker (1990); Strong and Walker (1993); Harris, Lang, and Moller (1994); Collins, Pincus, and Xie (1999); Francis and Schipper (1999); Dhaliwal, Subramanyam, and Trezevant (1999); Sarlo Neto (2004); Costa and Lopes (2007); Lopes, Sant'Anna, and Costa (2007); Galdi and Lopes (2008); Bastos, Nakamura, David, and Rotta (2009), Malacrida (2009) and Zanini, Cañibano, and Zani (2010).

Various authors, such as Brown et al. (1999); Kothari (2001); Holthausen and Watts (2001); and Barth, Beaver, and Landsman (2001) began the debate on the relationship between the relevance of accounting information and alternative accounting standards and rules.

Based on this theoretical framework, some studies tried to show the impact of changes in accounting standards on the relevance of the information produced by accounting and, more recently, on the effects of the process of harmonization with International Accounting Standards (IFRS).

In this area, the work of Bartov, Goldberg, and Kim (2005), Hung and Subramanyam (2007), Barth, Landsman, and Lang 
(2008), Chalmers, Clinch, and Godfrey (2008), Morais and Curto (2009), Chalmers, Clinch, and Godfrey (2009), Kadri, Aziz, and Ibrahim (2009) and Lima (2011) showed gains in the relevance of accounting information when there was a migration from a local standard to the international standard. In the contrary sense, the work of Niskaen, Kinnunen, and Kasanen (2000), Van der Meulen, Gaeremynck, and Willekens (2007) and Morais and Curto (2008) showed that changes resulting from the process of accounting harmonization with IFRS did not give rise to any gains in relevance, or that any such changes were not significant.

That is the context of this study, which examines the relevance of accounting information in an environment of changes, especially in the context of presentation of the Value Added Statement (VAS) becoming obligatory for Brazilian listed companies.

\section{THE VALUE ADDED STATEMENT (VAS)}

The Value Added Statement (VAS, or DVA as referred to in Brazil) aims to report the wealth generated by a company, and its distribution between the elements that contribute to the generation of that wealth, i.e. to set out the portion of the value added that is allocated to: holders of capital; other financiers of the entity's activity; employees; society as a whole - and how much is retained in the company.

Value added refers to the increase in wealth generated by the productive use of the firm's resources before its allocation among shareholders, bondholders, workers, and the government. Thus, while the profit is the final return earned by the shareholders, the value added refers to the total return earned by the team of workers, capital providers, and the government. (Riahi-Belkaoui, 1992, p. 1)

The wealth created, the subject of the DVA, is understood to mean the increase in value that the company attributes to the inputs of production for which payment was made to other parties during the production process. Gross wealth created can be calculated as the arithmetic difference between the value received as a result of sales and the amount paid for inputs to outside parties; net wealth created is understood to be gross wealth created adjusted by the effect of depreciation.

The information used in the Value Added Statement is, normally, extracted from the Profit and Loss Account (PLA); but they have complementary, rather than similar, objectives. The priority of the PLA is to emphasize net profit, while the priority of the VAS is to show the portion of value added that is allocated to the holders of the capital. In the PLA the other portions of value added that are allocated to employees, to the government and to external financiers appear as expenses.

It can be said that the PLA uses the criterion of type, while the VAS uses the criterion of benefit. For example in the PLA the salaries of employees involved in the production process are considered as costs, and the salaries of management staff as expenses. In the DVA, whatever their nature - cost or expense - salaries paid are part of the value added allocated to employees, that is to say, the criterion of the benefit of the income, on its own, is used (Iudícibus, Martins, Gelbcke, \& Santos, 2010).

The VAS became better known at the end of the 1970s in various European countries, achieving popularity in the United Kingdom, with the publication of The Corporate Report, in 1975, by the Accounting Standards Steering Committee. That publication, among other things, recommended a statement of Value Added, showing how the benefits of the efforts of the enterprise are shared between employees, providers of capital, the state and reinvestment. The recommendation was accepted by the UK government and, in 1997, a legislative proposal put forward that the "value added statement would be the future of reporting" (Burchell, Clubb, \& Hopwood, 1985; Riahi-Belkaoui, 1992). The result was that the number of companies that prepared a VAS increased, each year. A survey in 1980, in the UK, reported that one-fifth of large companies produced a VAS in that period (Riahi-Belkaoui, 1992).

In Brazil, until 2007, the VAS was not obligatory. However, the Brazilian Securities Commission (Comissão de Valores Mobiliários, or CVM) had been encouraging companies to prepare and publish the VAS since 1992. It was only in December 2007 that Law 11638/07 made publication of the VAS obligatory for listed companies.

The current Corporate Law in Brazil considers the VAS to be a financial statement similar to the other statements, based on the data extracted from the accounting records. The Accounting Pronouncements Committee (Comitê de Pronunciamentos Contábeis, or CPC), in Technical Pronouncement CPC 09 (of 2008), established the framework for preparation and disclosure of the VAS, and stated that it is one of the elements comprising the set of a company's financial statements, and that the great majority of the data for its preparation is obtained from the Profit and Loss Account. The model presented by the CPC is very similar to the model suggested by FIPECAFI, which was used by many companies before it became obligatory. CPC 09 specifies that the model to be followed for the VAS is in two parts. The function of the first part is to show the total value added to be distributed, which includes the net value added produced by the entity, plus the total of value added received by transfer, and can be represented as: 
(Revenue) - (Inputs acquired from third parties) - (Depreciation, amortization and depletion) + (Value added received by transfer)

The function of the second part of the VAS is to show how the value added is distributed between the agents that contributed to its generation: (i) employees: through salaries and benefits received, and payments to the employees' FGTS funds; (ii) the government: through federal, state and municipal taxes, which represent the remuneration for the social, political and economic structure that provided the conditions necessary for the company to operate; (iii) financing entities: remuneration of capital from third parties, through interest, rentals, rights of authorship, etc.; and (iv) holders of the company's capital: remuneration of that capital, through dividends, Interest on Equity [a specifically Brazilian alternative form of dividends], retained earnings and/or losses for the period.

The model for a VAS given by CPC 09 does not include voluntary contributions, and investments of funds in the community as a whole, nor contributions allocated to environmental issues. On this subject, Fregonesi (2009) proposes that social and environmental investments should be declared separately in the DVA, in a specific line within the listing of purposes of allocation of value added, and should include investments with the following features: (i) there is a disbursement by the investor company that is separate from and in addition to payments expended on the production process, or, at least, the amount should have been recorded in the company's accounting; (ii) there is a benefit for the community further to those provided by the company's existence alone; (iii) the final consumption of the good or service that is the subject of social investment takes place in the community; (iv) the disbursement is not a compensation for negative external factors generated by the production process; (v) the disbursement does not represent consumption of goods or services used in the production process; and (vi) there is no use of a tax incentive system in the form of deduction from tax payable.

De Luca (1998) considers that the VAS is part of the 'social statement' whose purpose is to present information of an economic nature to the various users, demonstrating the economic performance of the company and its relationships with society. In the view of Santos (2007), the VAS is a component of the Social Statement and 'should be understood as the most competent manner created by Accounting of assisting in the measurement and reporting of an entity's capacity to generate, and distribute, wealth' (Santos, 2007, p. 37). Note that both Santos (2007) and De Luca (1998) take the view that the VAS is an integral part of the 'Social Statement'.

Machado (2010) takes the view that the VAS stands out from the other components of the Social Statement, in visibility and in significance, especially because it has a standard form, enabling comparisons; its publication is obligatory for listed companies; and it uses data taken from the accounting, which gives it increased credibility, especially when the accounting is audited. For these reasons, it is of- ten treated separately from the Social statement, and presented in a manner similar to the other accounting statements, such as the PLA, the Statement of financial position (balance sheet), and the Statement of cash flow. In other words it is understood that due to its relevance, the VAS can be regarded both as the economic component of the social statement, and the social component of the financial statements.

Riahi-Belkaoui (1992) states that the VAS has the following advantages: (i) it provides a good organizational climate for workers, by highlighting their importance for the company's final result; (ii) it supplies a more practical manner of agreeing bonuses, with the possibility of tying them to value added; (iii) it is helpful in predictions and diagnostics; (iv) it helps in the measurement of national income; (v) it serves as a measure of scale and size, for companies; (vi) it serves as a basis for negotiations with employees; (vii) it helps in forecasting of profits, expected returns and the total risk associated with securities; (viii) it demonstrates the portion of value added that relates to the employees, indicating the scale of their importance to management; (ix) it provides a better image of the company's policies on re-investment, by showing separately the funds generated internally for replacement of fixed assets; (x) for multinationals, it provides information to the host country, as to their contributions to the process of local economic development; and (xi) it serves as an index of performance.

As well as the advantages of the VAS put forward by Riahi-Belkaoui (1992), especially in the Brazilian context, it can be used as a tool to evaluate companies' contributions when granting tax benefits - as well as being an alternative for calculation of GDP. As Santos (2007, p. 38) adds: '[...] it appears to be beyond doubt that it helps in the calculation of GDP and of extremely important social indicators. In this statement, decisions on investments by area, region, state, etc. will have an excellent instrument for the solution of conflicts.'

Internationally, empirical investigations on the VAS are not plentiful, possibly because international accounting standards do not include the VAS as part of the group of financial statements to be presented in the annual report, so that their disclosure is voluntary (Van Staden, 2000). The existing studies include investigations on the use of the VAS (Van Staden, 1998; Stainbank, 2009), and studies focused on the magnitude of their information content (Riahi-Belkaoui \& Fekrat, 1994; Riahi-Belkaoui \& Picur, 1994; Riahi-Belkaoui \& Picur, 1999).

Riahi-Belkaoui and Fekrat (1994) analyzed the variation and persistence of performance indicators derived from the value added statement, and indicators extracted from the financial statements. The variables they used were net value added, operational cash flow, representing a metric arising from the cash method of reporting, and profit, representing a method based on the accrual method. Data was used from 673 US companies, over the period 19811990. The results showed indicators based on net value added presenting lower variability and greater persistence than indicators based on net profit or operational cash flow. 
Also, the authors highlighted that accounting risk measures based on net value added have a higher association with the market than measures based on profit or cash flow.

The utility of net cash flow for explaining the return on shares of a sample of US companies was investigated by Riahi-Belkaoui and Picur (1994). The study investigated whether net value added and variation in net value added were relevant for predicting return. For this, the authors assumed (i) that the stock price reflects information that is included in the annual net value added of a past time series; and (ii) that the stock price reflects information from a past series on annual variation of net value added. The result of the study indicated that both value added, and its variation, are relevant in indicating the return on shares; and that net value added has a better association with return than the variation in net value added.

Riahi-Belkaoui and Picur (1999) evaluated the usefulness of replacing profit by net value added in a model for valuation of companies. For this study, they used the model of Feltham and Ohlson (1995), replacing profit, as a measure of wealth, by net value added. The sample of the study was the companies listed on the NYSE and AMEX that had data for the period from 1978 to 1995 in COMPUSTAT: a total of 3,999 observations. The results indicated that net value added is more successful than profit for predicting price. These authors highlight the need for valuation models to include relevant elements of information that are not components of profit, such as net value added; they also highlight the predictive power of net value added.

In Brazil some studies, from this same point of view, deserve mention. Scherer (2006) investigated whether value added, as supplied by the VAS spontaneously published by companies in Brazil over the period from 2000 to 2004, was relevant, for the Brazilian capital markets. With a very si- milar methodology to the one used in the present study, the author concluded that value added is a significant element of information, although it was not shown to be superior to profit and stockholders' equity.

In the study by Crippa and Coelho (2012), there is the same line of investigation, but using a sample of listed companies in the period from 2007 to 2010, which included a period during which publication of the VAS was mandatory. The authors found evidence that there is a significant positive relationship between the wealth generated by the companies of the sample and the return on their shares; and thus concluded that wealth created was relevant for the Brazilian capital market.

Barros, Catapan, Scherer, and Isidoro (2013) continued Scherer's study of 2006, but analyzing a more recent period, during the whole of which publication of the VAS was obligatory in Brazil. However, the results were very different from those found by Scherer (2006), since this study found no evidence of relevance of value added, with the exception of the companies listed on the specialized segments of the BM\&FBOVESPA (the São Paulo Stock Exchange) that require commitments to higher levels of corporate governance.

Finally, more recently, the study by Martins, Machado, and Callado (2014) evaluated how much value relevance the Statement of Cash Flow and the VAS added to the group of financial statements in the context of the Brazilian equities market. Their principal result was to show that the VAS, represented by the variable Wealth Created, did not show any information content added in isolation into the group of financial statements, nor when added jointly with the Statement of Cash Flow. These authors took the view that this can be explained by the fact that the VAS does not present new content, beyond what has already been presented in the Profit and Loss Account.

\section{METHODOLOGY}

\subsection{Characterization of the investigation.}

A choice was made in favor of an empirical-analytic study. According to Martins (2002, p. 34), “(...) these are approaches using markedly quantitative techniques of collection, treatment and analysis (...). There is a strong focus on the causal relationship between variables. Validation of scientific proof is sought through tests with instruments, degrees of significance, and systematization of operational definitions".

\subsection{Sample.}

The process of sampling is not probabilistic, since it starts with a naturally restricted universe: the companies chosen were those on the listing in the database of Melhores \& Maiores, an annual publication of Exame Magazine, in partnership with FIPECAFI.

To be part of the sample, the companies had to have the following characteristics:
- Not be a listed financial company.

- Have information available on the databases of Melhores \& Maiores, and Economática, in the period from 2005 to 2011.

The resulting database of Exame and Fipecafi provided a total of 1,271 units of analysis, of which 376 units did not have valid information, leading to a total of 895 units. For 184 of these, information was not found in the database of Economática, resulting in 711 valid units for analysis.

The final sample, thus, comprises these 711 observations of 172 non-financial listed companies, which were included in the database of Melhores \& Maiores, which presented Value added statements (VASs), in the period from 2005 to 2011, and which had the other necessary information available. Each company, in each year, was considered as a unit for analysis. Thus, the regressions presented for analysis of value relevance are based on a 'pooling' approach. 
Finally, the study has a possible limitation in that it includes companies that presented VASs voluntarily in the period from 2005 to 2007 . This could result in the study having a bias in that only the companies that had some interest in the publication of VASs brought this information into evidence.

\subsection{Econometric model.}

Adopting the methodology of Collins et al. (1997), Costa and Lopes (2007), Morais and Curto (2008) and Macedo, Machado, Murcia, and Machado (2011), a linear regression was used to analyze whether the VAS presented value relevant information content, as per Equations 1:

$\mathrm{p}_{\mathrm{i}, \mathrm{t}}=\mathrm{a}_{0}+\mathrm{a}_{1} W C P S_{i, t}+\varepsilon_{i}$

Where:

$\mathrm{p}_{\mathrm{i}, \mathrm{t}}=\mathrm{A}$ dependent variable, representing the share price of company $i$, at time $t$;

$a_{0}=$ Intercept;

$\mathrm{a}_{1}=$ Slope coefficient;

WCPS $=$ An independent variable resulting from division of wealth created, taken from the VAS, by the number of the shares of company $i$, at time $t$;

$\varepsilon=$ Random error (white noise) with normal distribution, zero mean and constant variance.

Having in mind that other factors, as well as wealth created, may influence the share price, certain control variables were included in the empirical analysis, to ensure robustness. These are: Net profit per share (NPPS) and Stockholders' equity per share (SEPS) - since these variables were found in a large part of the studies on value relevance, such as Collins, et al. (1997), Costa and Lopes (2007), Morais and Curto (2008) and Macedo et al. (2011).

Thus, an analysis was made of whether WCPS has relevant information content, after control by NPPS and by SEPS. The objective is to analyze whether there is an information gain when WCPS (Equation 3) is added to the model with NPPS and SEPS (Equation 2).

$\mathrm{p}_{\mathrm{i}, \mathrm{t}}=\mathrm{a}_{0}+\mathrm{a}_{1} N P P S_{i, t}+\mathrm{a}_{2} \operatorname{SEPS}_{i, t}+\varepsilon_{i}$ $\mathrm{p}_{\mathrm{i}, \mathrm{t}}=\mathrm{a}_{0}+\mathrm{a}_{1} N P P S_{i, t}+\mathrm{a}_{2} \operatorname{SEPS}_{i, t}+\mathrm{a}_{3} W C P S_{i, t}+\varepsilon_{i}$

To analyze whether there was a gain or a loss of content when the WCPS was included, the adjusted $\mathrm{R}^{2}$ of the regressions was compared. Thus, if the adjusted $\mathrm{R}^{2}$ of Equation 3 was greater than the adjusted $\mathrm{R}^{2}$ of Equation 2, it could be concluded that there was an information gain and, thus, that the VAS has value relevance. Additionally, the Wald test was used.

The comparison of the models using the Wald test, via $\mathrm{F}$ statistics, is preferable to the comparison through adjusted $R^{2}$ (Heij, de Boer, Franses, Kloek, \& van Dijk, 2004). For this, the original model, referred to as the restricted model (Equation 2), needs to be compared with the model with the new explanatory variables added, referred to as the unrestricted model (Equation 3). The objective is to evaluate whether the inclusion of the variable WCPS improves the explanatory power of the model. For this test, the $F$ statistic is calculated as per Equation 4:

$\frac{\left(R_{I R}^{2}-R_{R}^{2}\right) / m}{\left(1-R_{I R}^{2}\right) / n-k}$

Where:

$R_{I R}^{2}: R^{2}$ from the unrestricted model (Equation 3);

$R_{R}^{2}: R^{2}$ from the restricted model (Equation 2);

$m$ : number of restrictions;

$n$ : number of observations;

$k$ : number of coefficients of the unrestricted model.

For price, the price of the company's share with the highest liquidity on April 30 of the year subsequent to that of the published financial statements was used. The data for wealth created were obtained from the database of FIPECAFI. The information on stock price, number of shares, net profit and stockholders' equity were extracted from the database of Economática. Since the data for wealth created were supplied in US dollars, the information on stock price, net profit and stockholders' equity was also collected in US dollars.

Finally, note that every analysis of the relevance of the VAS is focused on a single proxy: Wealth created per share (WCPS), thus, the results of the investigation are also subject to that limitation.

\section{RESULTS: PRESENTATION AND ANALYSIS}

Figure 1 shows the average WCPS of the companies contained in the sample. It is seen that the companies generated, on average, wealth of US $\$ 5.90$ per share, with a minimum of US\$4.47 in 2009, and a maximum of US\$7.33, in 2007. It is also seen that there is a trend of growth in generation of wealth in the period 2005 through 2007, with the amounts falling considerably in 2008 and 2009 , possibly due to the international financial crisis, with a slight recovery in 2010 and 2011. 


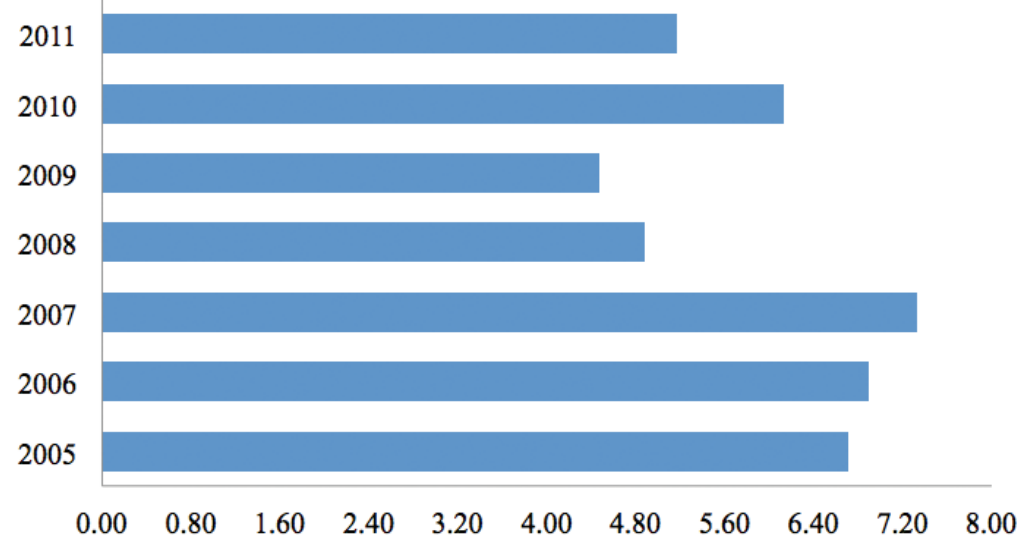

Figure 1 Average WCPS of the sample.

Table 1 shows the results of the regression, using wealth created per share (WCPS) as the explanatory varia- ble and the share price as the dependent variable, as per Equation 1.

Table 1

Results of the regression with WCPS, and without Control variables

\begin{tabular}{|c|c|c|c|c|}
\hline \multicolumn{5}{|c|}{ Panel A } \\
\hline Explanatory variable & Coefficient & Standard error* & T-statistic & $p$-value \\
\hline $\mathrm{C}$ & 4.823 & 0.903 & 5.339 & 0.000 \\
\hline WCPS & 0.948 & 0.182 & 5.205 & 0.000 \\
\hline \multicolumn{5}{|c|}{ Panel B } \\
\hline Description & Value & \multicolumn{2}{|c|}{ Description } & Value \\
\hline $\mathrm{R}^{2}$ & 0.650 & \multicolumn{2}{|c|}{$\mathrm{F}$ test (statistic) } & 1318.40 \\
\hline Adjusted $\mathrm{R}^{2}$ & 0.650 & \multicolumn{2}{|c|}{ F test ( $p$-value) } & 0.000 \\
\hline Schwarz & 7.660 & \multicolumn{2}{|c|}{ White test (statistic) } & 431.91 \\
\hline Akaike & 7.647 & \multicolumn{2}{|c|}{ White test ( $p$-value) } & 0.000 \\
\hline Jarque-Bera (statistic) & 28028.67 & \multicolumn{2}{|c|}{ Durbin-Watson*** } & 1.94 \\
\hline Jarque-Bera $(p \text {-value })^{* *}$ & 0.000 & \multicolumn{2}{|c|}{ Number of observations } & 711 \\
\hline
\end{tabular}

* Estimated standard errors with correction for White's heteroskedasticity, since the null hypothesis of homoskedastic variances was rejected, at the level of $1 \%$.

**In accordance with the central limit theorem and considering that 711 observations were used, the supposition of normality can be relaxed (Brooks, 2002). Also, the White correction increases the standard error, reducing the $t$ statistic, making its estimation more robust.

*** The hypothesis of autocorrelation in the residuals is rejected.

According to Table 1, Panel B, the estimated regression, considered in isolation, was statistically significant at the level of $1 \%$, since the $p$-value obtained for the F statistic is lower than 0.01 . A coefficient of determination of 0.650 was obtained, indicating that $65.0 \%$ of the variation in the stock price is explained by the variation in wealth created. In terms of significance, Panel A, of Table 1, through the $t$ statistic, indicates that the variable WCPS was statistically significant at the level of $1 \%$, and with the predicted sign. This shows that WCPS is a variable that is able to explain the stock price, that is to say, that wealth created is a relevant item of information for the Brazilian capital markets. In the first instance, these results confirm the findings of Riahi-Belkaoui and Picur (1994), Riahi-Belkaoui and Picur (1999), Scherer (2006) and Crippa and Coelho (2012); but are partially in disagreement with the results obtained by Barros et al. (2013) and divergent from the study by Martins et al. (2014).

Table 2 shows the results of the regression, using net profit per share (NPPS) and stockholders' equity per share (SEPS) as explanatory variable and the stock price as dependent variable, as per Equation 2.

According to Table 2, Panel B, the estimated regression, considered in isolation, was statistically significant at the level of $1 \%$, since the p-value obtained for the F statistic is less than 0.01 . A coefficient of determination of 0.713 was obtained, showing that $71.3 \%$ of the variation in the share price is explained by the variation of NPPS and SEPS. As to significance, Panel A, of Table 2, through the $t$ statistic, indicates that both the variable NPPS and SEPS were statistically significant at the level of $1 \%$, and had the predicted sign. Thus, there is confirmation of the relevance of information on profit and stockholders' equity for the Brazilian capital markets. 
Results of the regression with NPPS and SEPS

\begin{tabular}{|c|c|c|c|c|}
\hline \multicolumn{5}{|c|}{ Panel A } \\
\hline Explanatory variable & Coefficient & Standard error* & T-statistic & $p$-value \\
\hline $\mathrm{C}$ & 4.830 & 0.754 & 6.402 & 0.000 \\
\hline SEPS & 0.508 & 0.122 & 4.159 & 0.000 \\
\hline NPPS & 2.786 & 0.737 & 3.782 & 0.000 \\
\hline \multicolumn{5}{|c|}{ Panel B } \\
\hline Description & Value & \multicolumn{2}{|c|}{ Description } & Value \\
\hline $\mathrm{R}^{2}$ & 0.713 & \multicolumn{2}{|c|}{ F test (statistic) } & 879.51 \\
\hline Adjusted $\mathrm{R}^{2}$ & 0.712 & \multicolumn{2}{|c|}{ F test ( $p$-value) } & 0.000 \\
\hline Schwarz & 7.471 & \multicolumn{2}{|c|}{ White test (statistic) } & 155.83 \\
\hline Akaike & 7.452 & \multicolumn{2}{|c|}{ White test ( $p$-value) } & 0.000 \\
\hline Jarque-Bera $(p \text {-value })^{* *}$ & 0.000 & \multicolumn{2}{|c|}{ Number of observations } & 711 \\
\hline
\end{tabular}

* Estimated standard errors with correction for White's heteroskedasticity, since the null hypothesis of homoskedastic variances was rejected, at the level of $1 \%$.

**In accordance with the central limit theorem and considering that 711 observations were used, the supposition of normality can be relaxed (Brooks, 2002). Also, the White correction increases the standard error, reducing the $t$ statistic, making its estimation more robust.

*** The hypothesis of autocorrelation in the residuals is rejected.

To detect the presence of multicolinearity, variance inflation factor (VIF) tests were used. A VIF of 2.573 was obtained, it being concluded that there is a tolerable level of colinearity (Levine, Berenson, \& Stephan, 2000).

To verify whether the results obtained in Table 1 were consistent, that is to say, whether the VAS has relevant information content, control variables were included, to ascertain whether there was a change in the sign or in the statistical significance of the variable WCPS.

It is seen that the inclusion of the control variables NPPS and SEPS (Equation 3) did not change the significance, nor the sign of the variable WCPS (Table 3). Also, an improvement in the adjusted coefficient of determination is seen, in relation to the results of Table 2 . An information gain is seen, also, from analysis of the adjusted coefficient of determination (Tables 2 and 3), when the WCPS is added in the model with NPPS and SEPS (adjusted $\mathrm{R}^{2} 0.712$ ), since the model that uses WCPS (Table 3 ) presented a larger adjusted $\mathrm{R}^{2}(0.755)$.

\begin{tabular}{|c|c|c|c|c|}
\hline \multicolumn{5}{|c|}{ Panel A } \\
\hline Explanatory variable & Coefficient & Standard error* & T-statistic & $p$-value \\
\hline C & 4.212 & 0.728 & 5.791 & 0.000 \\
\hline NPPS & 1.496 & 0.645 & 2.319 & 0.021 \\
\hline SEPS & 0.381 & 0.105 & 3.645 & 0.000 \\
\hline WCPS & 0.425 & 0.137 & 3.107 & 0.002 \\
\hline \multicolumn{5}{|c|}{ Panel B } \\
\hline Description & Value & \multicolumn{2}{|c|}{ Description } & Value \\
\hline $\mathrm{R}^{2}$ & 0.757 & \multicolumn{2}{|c|}{ F test (statistic) } & 732.22 \\
\hline Adjusted $\mathrm{R}^{2}$ & 0.755 & \multicolumn{2}{|c|}{$F$ test ( $p$-value) } & 0.000 \\
\hline Schwarz & 7.316 & \multicolumn{2}{|c|}{ White test (statistic) } & 299.12 \\
\hline Akaike & 7.291 & \multicolumn{2}{|c|}{ White test ( $p$-value) } & 0.000 \\
\hline Jarque-Bera (statistic) & 13272.60 & \multicolumn{2}{|c|}{ Durbin-Watson** } & 1.92 \\
\hline Jarque-Bera $(p \text {-value })^{* *}$ & 0.000 & \multicolumn{2}{|c|}{ Number of observations } & 711 \\
\hline
\end{tabular}

* Estimated standard errors with correction for White's heteroskedasticity, since the null hypothesis of homoskedastic variances was rejected, at the level of $1 \%$.

**In accordance with the central limit theorem and considering that 711 observations were used, the supposition of normality can be relaxed (Brooks, 2002). Also, the White correction increases the standard error, reducing the $t$ statistic, making its estimation more robust.

*** The hypothesis of autocorrelation in the residuals is rejected.

To detect the presence of multicolinearity, variance inflation factor (VIF) tests were used. VIF values of 2.892, 3.444 and 3.013 were obtained for the variables SEPS, NPPS and WCPS, it being concluded that there is tolerable colinearity (Levine et al., 2000). 
The analysis of information gain or loss, with the inclusion of WCPS, according to the Wald test, reveals that the model of Equation 3 showed itself to be significantly superior to the model of Equation 2, at the level of 1\% ( $p$ value of 0.002 , for $F$ statistic of 9.654). Thus, it can be concluded that the inclusion of the WCPS variable in the model of Equation 2 improves the explanatory power of that model. Thus, it can be concluded that the variable WCPS has value relevance.

With this, it is perceived that the results obtained up to this point show that Wealth created - information which comes from the VAS - not only has relevance for the Brazilian capital markets, but also adds information content to the information on profit and stockholders' equity. That is to say, it is perceived that there is marginal information content in the VAS for investors. This is a finding that previous investigators had not observed.

As a secondary objective, this article sought to analyze whether WCPS represents a better proxy for the result of a company than NPPS. For this, firstly, it was found, using a Wald test, that the respective variables added information gain, when included in the model with SEPS (restricted model), as per Equations 2, 5 and 6.

$\mathrm{p}_{\mathrm{i}, \mathrm{t}}=\mathrm{a}_{0}+\mathrm{a}_{1} \operatorname{SEPS} S_{i, t}+\varepsilon_{i}$

$\mathrm{p}_{\mathrm{i}, \mathrm{t}}=\mathrm{a}_{0}+\mathrm{a}_{1} \operatorname{SEPS}_{i, t}+\mathrm{a}_{2} W C P S_{i, t}+\varepsilon_{i}$

According to the Wald test, both the model of Equation 2 ( $p$ value 0.00 , for $\mathrm{F}$ statistic 14.30 ), and the model of Equation 6 ( $p$ value 0.00, for F statistic of 17.42), showed themselves to be significantly superior to the model of Equation 5, at the level of 1\%. Thus, it can be concluded that the inclusion both of the variable WCPS, and also of NPPS, in the model of Equation 5, improves the explanatory power of that model. Thus, it can be concluded that the variables WCPS and NPPS have value relevance.

\begin{tabular}{|c|c|c|c|c|}
\hline \multicolumn{5}{|c|}{ Panel A } \\
\hline Explanatory variable & Coefficient & Standard error* & T-statistic & $p$-value \\
\hline $\mathrm{C}$ & 4.076 & 0.785 & 5.193 & 0.000 \\
\hline SEPS & 0.486 & 0.124 & 3.914 & 0.000 \\
\hline WCPS & 0.550 & 0.132 & 4.174 & 0.000 \\
\hline \multicolumn{5}{|c|}{ Panel B } \\
\hline Description & Value & \multicolumn{2}{|c|}{ Description } & Value \\
\hline $\mathrm{R}^{2}$ & 0.742 & \multicolumn{2}{|c|}{ F test (statistic) } & 1016.67 \\
\hline Adjusted $\mathrm{R}^{2}$ & 0.741 & \multicolumn{2}{|c|}{ F test ( $p$-value) } & 0.000 \\
\hline Schwarz & 7.366 & \multicolumn{2}{|c|}{ White test (statistic) } & 240.16 \\
\hline Akaike & 7.347 & \multicolumn{2}{|c|}{ White test ( $p$-value) } & 0.000 \\
\hline Jarque-Bera $(p \text {-value })^{* *}$ & 0.000 & \multicolumn{2}{|c|}{ Number of observations } & 711 \\
\hline
\end{tabular}

* Estimated standard errors with correction for White's heteroskedasticity, since the null hypothesis of homoskedastic variances was rejected, at the level of $1 \%$. **In accordance with the central limit theorem and considering that 711 observations were used, the supposition of normality can be relaxed (Brooks, 2002). Also, the White correction increases the standard error, reducing the $t$ statistic, making its estimation more robust.

*** The hypothesis of autocorrelation in the residuals is rejected.

To detect the presence of multi-colinearity, VIF (variance inflation factor) tests were used. A VIF of 2.251 was obtained, it being concluded that there was a tolerable level of colinearity (Levine et al., 2000).

The models represented by Equations 3 (Table 3 ) and 6 (Table 4) were then compared. It is observed that, when including NPPS in the model with SEPS and WCPS (Table 3), there is practically no alteration in the adjusted coefficient of determination. Further, according to the Wald test, the model represented by Equation 3 did not show itself to be superior to the model of Equation 6 ( $p$ value 0.021 , for $F$ statistic 5.38), at the level of $1 \%$ of significance. These results are contrary to those obtained when the models represented by Equations 2 and 3 were compared.

Further, when comparing the adjusted coefficient of determination and the Schwarz information criterion of the models represented by Equations 2 (Table 2) and 6 (Table 4), a larger adjusted coefficient of determination is perceived for the model with WCPS (0.741), compared to the model with NPPS (0.712), and also lower value for the Schwarz information criterion (7.366 and 7.471, respectively). In view of this, there are indications that the market reacts more to WCPS than to NPPS. Thus, the results obtained could be revealing evidence that, from the point of view of the capital markets, WCPS could be a better proxy for the result of the company than NPPS, which corroborates the results of Riahi-Belkaoui and Picur (1999) and goes against the findings of Scherer (2006). 
Studies of value relevance aim to find the relevance of a given item of accounting information to the capital markets. The objective of these studies is to find out whether certain information is reflected in the stock price of a company. Thus, for the accounting information to have relevant information content its coefficient in the regression equation needs to be significantly different from zero.

Within this context, the aim of this study was to analyze the relevance of the information content of the Value Added Statement (VAS) in the Brazilian market. For this, the relationship between the price of shares and wealth created per share (WCPS) was analyzed, for the period from 2005 to 2011, of non-financial listed companies included in the Melhores \& Maiores annual publication of Exame Magazine. As a secondary objective, this article has sought to analyze whether WCPS represents a better proxy for a company's result than NPPS.

The empirical evidence found suggests that the VAS has relevant information content, because it succeeds in explaining the stock price variation of the companies researched. Also, the relationship between WCPS and the stock price was shown to be significant, even after the inclusion of the control variables.

It is observed that, when including NPPS in the model with SEPS and WCPS, there is practically no alteration in the adjusted coefficient of determination. Further, the comparison between the models with SEPS and WCPS and with SEPS and NPPS revealed evidence that the market reacts more to WCPS than to NPPS. Thus, the results obtained reveal indications that WCPS represents a better proxy for the result of the company than NPPS, corroborating the results of Riahi-Belkaoui and Fekrat (1994), Riahi-Belkaoui and Picur (1994) and Riahi-Belkaoui and Picur (1999).
Possibly, this result is justified because wealth created is a wider measure of the performance of the company than net profit, which represents only the portion of the wealth created that is allocated to the holders of capital. Thus, it is presumed that the market expects from companies not only remuneration of their own capital, but principally, the generation of wealth that can guarantee future viability, and also remunerate all those whose efforts have generated the wealth. It is supposed, also, that the market may be taking into account the social responsibility of the company, which is also evidenced in the VAS. The result corroborates the studies of Scherer (2006) and Crippa and Coelho (2012). However, it is contrary to the findings of Barros et al. (2013) and Martins et al. (2014).

In general, the results show that the process of changes of accounting standards in Brazil is adding information content to the financial statements in relation to the capital markets, that is to say, the requirement for the VAS improves the information quality of the financial statements. This is in harmony with the results of Bartov et al. (2005), Hung and Subramanyam (2007), Barth et al. (2008), Chalmers et al. (2008), Morais and Curto (2009), Chalmers et al. (2009), Kadri et al. (2009) and Lima (2011), who also found an improvement in the information content of the financial statements after the process of convergence to international accounting standards.

Finally, it is possible to raise the hypothesis that VAS has provided utility to the investor, and to suggest that further studies about the information content should be made, increasing the number of observations, and also including other control variables and analyzes that differentiate the companies studied, especially in relation to the adoption of social-environmental practices, adoption of governance practices, the sector to which the company belongs and the manner of distribution of the value added.

\section{References}

Amir, E., Harris, T. S., \& Venutti, E. K. (1993). A comparison of value relevance of US versus non-US-GAAP accounting measures using Form 20-F reconciliations. Journal of Accounting Research Supplement, 31, 230-264

Ball, R., \& Brown, P. (1968). An empirical evaluation of accounting income numbers, Journal of Accounting Research, 6, 159-177.

Barros; C. M. E., Catapan, A., Scherer, L. M., \& Isidoro, C. (2013). Relevância do valor adicionado: um estudo empírico em sociedades anônimas abertas brasileiras. Registro Contábil, 4 (3), 147-162.

Barth, M. E., Beaver, W. H., \& Landsman, W. R. (2001). The relevance of value relevance literature for financial accounting standard setting: another view. Journal of Accounting and Economics, 31, 77-104.
Barth, M. E., Landsman, W. R., \& Lang, M. H. (2008). International accounting standards and accounting quality. Journal of Accounting Research, 46 (3), 467-498.

Bartov, E., Goldberg, S. R., \& Kim, M. (2005). Comparative value relevance among German, U.S., and international accounting standards: a German stock market perspective. Journal of Accounting, Auditing \& Finance, 20, 95-119.

Bastos, D. D., Nakamura, W. T., David, M., \& Rotta, U. A. S. (2009). A relação entre o retorno das ações e as métricas de desempenho: evidências empíricas para as companhias abertas no Brasil. REGE, 16 (3), 65-79.

Beaver, W. (1968). The information content of annual earnings announcements. Journal of Accounting Research, 6, 67-92. 
Beaver, W., Clarke, R., \& Wright, F. (1979). The association between unsystematic security returns and the magnitude of earnings forecast errors. Journal of Accounting Research, 17, 316-340.

Beaver, W., Lambert, R., \& Morse, D. (1980). The information content of security prices. Journal of Accounting and Economics, 2, 3-28.

Board, J. G. L., \& Walker, M. (1990). Intertemporal and cross-sectional variation in the association between unexpected accounting rates of return and abnormal returns. Journal of Accounting Research, 28 (1), 182-192.

Brooks, C. (2002). Introductory econometrics for finance. Cambridge: Cambridge University Press.

Brown, S., Lo, K., \& Lys, T. (1999). Use of $\mathrm{R}^{2}$ in accounting research: measuring canges in value relevance over the last four decades. Journal of Accounting and Economics, 28, 83-115.

Burchell, S., Clubb, C.; \& Hopwood, A. G. (1985). Accounting in its social context: towards a history of value added in the United Kingdom. Accounting, Organizations and Society, 10 (4), 381-413.

Chalmers, K., Clinch, G. J., \& Godfrey, J.'M. (2008). Adoption of international financial reporting standards: impact on the value relevance of intangible assets. Australian Accounting Review, 18 237-247.

Chalmers, K., Clinch, G. J., \& Godfrey, J. M. (2009). Changes in value relevance of financial information upon IFRS adoption. SSRN. Recuperado de www.ssrn.com.

Collins, D., Maydew, E. L., \& Weiss, L. (1997). Changes in the value relevance of earnings and book value over the past forty years. Journal of Accounting and Economics, 24, 39-67.

Collins, D., Pincus, M., \& Xie, H. (1999). Equity valuation and negative earnings: the role of book value equity. The Accounting Review, 74, 29-61.

Comitê de Pronunciamentos Contábeis (CPC). (2008). Pronunciamento técnico CPC 09: demonstração do valor adicionado. Brasília.

Costa, F. M., \& Lopes, A. B. (2007). Ajustes aos US-GAAP: estudo empírico sobre sua relevância para emprèsas brasileiras com ADRs negociadas em bolsa de Nova Iorque. Revista Contabilidade \& Finanças, Edição 30 anos de Doutorado, 45-57.

Crippa, M., \& Coelho, A. C. D. (2012, junho). Relevância e conteúdo informacional da demonstração do valor adicionado: evidências para o Brasil. Anais da Associação Nacional De Programas de PósGraduação em Ciências Contábeis, Florianópolis, SC, Brasil, 6.

De Luca, M. M. M. (1998). Demonstração do valor adicionado: do cálculo da riqueza criada pela empresa ao valor do PIB. São Paulo: Atlas.

Dhaliwal, D., Subramanyam, K. R., \& Trezevant, R. (1999). Is comprehensive income superior to net income as a measure of firm performance? Journal of Accounting and Economics, 26, 43-67.

Famá, E. F. (1970). Efficient markets: a review of theory and empirical work. Journal of Finance, 25 (2), 383-417.

Feltham, G. A., Ohlson, J. A. (1995). Valuation and clean surplus accounting for operating and financial activities. Contemporary Accounting Research, 11 (2), 689-731.

Foster, G. (1977). Quarterly accounting data: time-series properties and predictive-ability results. The Accounting Review, 52, 1-21.

Francis, J., \& Schipper, K. (1999). Have financial statements lost their relevance? Journal of Accounting Research, 37 (2), 319-352.

Fregonesi, M. S. F. A. (2009). Investimentos socioambientais na demonstração do valor adicionado: formação ou distribuição do valor adicionado? (Tese de Doutorado). Unịversidade de São Paulo, São Paulo, SP, Brasil.

Galdi, F. C., \& Lopes, A. B. (2008). Relação de longo prazo e causalidade entre o lucro contábil e o preço das ações: evidências do mercado latino-americano. RAUSP, 43 (2), 186-201.

Harris, T. S., Lang, M., \& Moller, H. P. (1994). The value relevance of German accounting measures: an empirical analysis. Journal of Accounting Research, 32, 187-209.

Heij, C., de Boer, P., Franses, P. H., Kloek, T., \& van Dijk, H. K. (2004) Econometric methods with applications in business and economics. Oxford: Oxford University Press.

Hendriksen, E. S., \& van Breda, M. F. (1999). Teoria da contabilidade. São Paulo: Atlas.

Holthausen, R. W., \& Watts, R. L. (2001). The relevance of value relevance literature for financial accounting standard setting. Journal of Accounting and Economics, 31, 3-75.

Hung, M. (2001). Accounting standards and value relevance of financial statements: an international analysis. Journal of Accounting and Economics, 30, 401-420.

Hung, M., \& Subramanyam, K. R. (2007). Financial statement effects of adopting international accounting standards: the case of Germany. Review of Accounting Studies, 12, 623-657.

Iudícibus, S., \& Lopes, A. B. (Coords.). (2004). Teoria avançada da contabilidade. São Paulo: Atlas.

Iudícibus, S., Martins, E., Gelbcke, E. R., \& Santos, A. (2010). Manual de contabilidade societária. São Paulo: Atlas.

Kadri, M. H., Aziz, R. A., \& Ibrahim, M. K. (2009). Value relevance of book value and earnings: evidence from two different financial reporting regimes: Journal of Financial Reporting \& Accounting, 7 (1) $1-16$.

Kothari, S. P. (2001): Capital markets research in accounting. Journal of Accounting and Economics, 31, 105-231.

Lei $n^{\circ}$. 6.404, de 15 de dezembro de 1976. (1976). Dispõe sobre as sociedades por ações. Diário Oficial da União. Brasília. (1976).

Lei $n^{\circ}$. 11.638, de 28 de dezembro de 2007. (2007). Altera e revoga dispositivos da Lei no 6.404, de 15 de dezembro de 1976, e da Lei no 6.385 , de 7 de dezembro de 1976, e estende às sociedades de grande porte disposições relativas à elaboração e divulgação de demonstrações financeiras. Diário Oficial da União. Brasília. (2007).

Levine, D. M., Berenson, M. L., \& Stephan, D. (2000). Estatística: teoria e aplicações. Rio de Janeiro: LTC.

Lima, J. B. N. (2011). A relevância da informação contábil e o processo de convergência para as normas IFRS no Brasil. (Tese de Doutorado). Universidade de São Paulo, São Paulo, SP, Brasil.

Lopes, A. B. (2001). A relevância da informação contábil para o mercado de capitais: o modelo de Ohlson aplicado à BOVESPA. (Tese de Doutorado). Universidade de São Paulo, São Paulo, SP, Brasil.

Lopes, A. B. (2002a). The value relevance of Brazilian accounting numbers: an empirical investigation. SSRN. Recuperado de www.ssrn.com.

Lopes, A. B. (2002b). A informação contábil e o mercado de capitais. São Paulo: Pioneira Thomson Learning.

Lopes, A. B.; Martins, E. (2005). Teoria da contabilidade: uma nova abordagem. São Paulo: Atlas.

Lopes, A. B., Sant'Anna, D. P., \& Costa, F. M. (2007). A relevância das informações contábeis na BOVESPA a partir do arcabouço teórico de Ohlson: avaliação dos modelos de residual income valuation e abnormal earnings growth. RAUSP, 42 (4), 497-510.

Macedo, M. A. S., Machado, M. A. V., Murcia, F. D., \& Machado, M. R. (2011). Análise do impacto da substituição da DOAR pela DFC: um estudo sob a perspectiva do value-relevance. Revista de Contabilidade e Finanças, 22 (57), 299-318.

Machado, M. R. (2010). As informações sociais e ambientais evidenciadas nos relatórios anuais das empresas: a percepção dos usuários. (Tese de Doutorado). Universidade de São Paulo, São Paulo, SP, Brasil.

Malacrida, M. J. C. (2009). A relevância do lucro líquido versus fluxo de caixa operacional para o mercado de ações brasileiro. (Tese de Doutorado). Universidade de São Paulo, São Paulo, SP, Brasil.

Martins, G. (2002). Manual para elaboração de.monografias e dissertações. (3. ed.). São Paulo: Atlas.

Martins, V. G., Machado, M. A. V. \& Callado, A. L. C.(2014). Análise da aditividade de value relevance da DFC e da DVA ao conjunto de demonstrações contábeis: evidências de empresas do mercado de capitais brasileiro. Contabilidade, Gestão e Governança, 17 (1), 74-94.

Medida Provisória $n^{\circ} 449$, de 3 de dezembro de 2008. (2008). Altera a legislação tributária federal relativa ao parcelamento ordinário de débitos tributários, concede remissão nos casos em que especifica, institui regime tributário de transição, e dá outras providências. Diário Oficial da União. Brasília. (2008)

Morais, A. I., \& Curto, J. D. (2008). Accounting quality and the adoption of IASB standards - portuguese evidence. Revista Contabilidade \& Finanças, 19 (48), 103-111.

Morais, A. I., \& Curto, J. D. (2009). Mandatory adoption of IASB standards: value relevance and country-specific factors. Australian Accounting Review, 19 (49), 128-143.

Niskanen, J., Kinnunen, J., \& Kasanen, E. (2000). The value relevance of IAS reconciliation components: empirical evidence from Finland Journal of Accounting and Public Policy; 19, 119-137.

Riahi-Belkaoui, A. (1992). Value added reporting: lessons for the United States. New York: Quorum Books.

Riahi-Belkaoui, A., \& Fekrat, M. A. (1994). The magic in value added merits of derived accounting indicator numbers. Managerial Finance, 20 (9), 3-15.

Riahi-Belkaoui, A., \& Picur, R. D. (1994). Net value added as an explanatory variable for returns. Managerial Finance, 20 (9), 56-64

Riahi-Belkaoui, A., \& Picur, R. D. (1999). The substitution of net value added for earnings in equity valuation. Managerial Finance, 25 (12), 66-78. 
Santos, A. (2007). Demonstração do valor adicionado: como elaborar e analisar a DVA: (2. ed.). São Paulo: Atlas.

Stainbank, L. J. (2009). The value added statement: does it add any value? Meditari Accountancy Research, 17 (2), 137-149.

Sarlo Netọ, A. (2004). A reação dos preços das ações à divulgação dos resultados contábeis: evidências empíricas sobre a capacidade informacional da contabilidade no mercado acionário brasileiro. (Dissertação de Mestrado). Fundação Instituto Capixaba de Pesquisas em Contabilidade, Economia e Finanças, Vitória, ES, Brasil.

Scherer, L. M. (2006). Valor adicionado: análise empírica de sua rélevância para as companhias abertas que publicam a demonstração do valor adicionado. (Tese de Doutorado). Universidade de São Paulo, São Paulo, SP, Brasil.

Strong, N., \& Walker, M. (1993). The explanatory power of earnings for stock returns. The Accounting Review, 68 (2), 385-399.

Van der Meulen, S., Gaeremynck, A., \& Willekens, M. (2007). Attribute differences between U.S. GAAP and IFRS earnings: an exploratory study. The International Journal of Accounting, 42, 123-142.

Van Staden, C. J. (1998). The usefulness of the value added statement in South Africa. Managerial Finance, 24 (11), 44-59.

Van Staden, C. J. (2000). The value added statement: bastion of social reporting or dinosaur of financial reporting? SSRN. Recuperado de www.papers.ssrn.com.

Yamamoto, M. M., \& Salotti, B. M. (2006). Informação contábil: estudos sobre a sua divulgação no mercado de capitais. São Paulo: Atlas.

Zanchet, A., \& Martins, G. A. (2011, setembro). Calculabilidade, contabilidade e performatividade: imbricações na institucionalização da demonstração do valor adicionado. Anais da Associação Nacional de Pós-Graduação e Pesquisa em Administração, Rio de Janeiro, RJ, Brasil, 35.

Zanini, F. A. M., Cañibano, L., \& Zani, J. (2010). Los indicadores contables tradicionales: relevancia como explicativos del valor de la empresa en el contexto de la nueva economía. El caso brasileño. BASE, 7 (2), 82-93. 